\title{
DEVELOPING MARKETING STRATEGY OF POULTRY MEAT SUPPLY IN EU- 28 COUNTRIES: MULTIVARIATE ANALYSIS APPROACH
}

\section{Miro Simonič, Ksenija Dumičić, Berislav Žmuk}

(1) Business School Murska Sobota, Murska Sobota, Slovenia (2) Full Professor in Tenure, Department of Statistics, University of Zagreb, Zagreb, Croatia (3) Senior Assistant, Department of Statistics, University of Zagreb, Zagreb, Croatia

Miro Simonič

Business School Murska Sobota Noršinska ul. 13, 900o Murska Sobota, Slovenia mirosimoni@gmail.com

Article info

Paper category: Preliminary paper Received: 23.6.2016.

Accepted: 22.2.2016. JEL classification: $\mathrm{M}_{41}, \mathrm{O}_{1}, \mathrm{P}_{45}, \mathrm{~N}_{5}$ 


\begin{abstract}
To create a concept of the marketing strategy, it is necessary to analyse the factors affecting the purchasing decisions of consumers. For the variables: production, import, export, and manufacturer's price we examine their impact on the marketing of poultry meat in the EU-28 in 2009 and 2011. Countries are grouped into clusters, their properties are analysed in relation to the mentioned variables. With multiple regression analysis, we find that there is a statistical correlation between high production and depending on the variable, and between the imports and exports as the independent variables. Based on the analysed data in the researched countries, we conclude that the qualitative development of the production of poultry meat required implementing sophisticated agricultural policy with low inputs prices and exploit all available spare resources.
\end{abstract}

\title{
Keywords:
}

cluster analysis; correlation; marketing strategy; multiple regression; poultry meat 


\section{INTRODUCTION}

The development of modern technology calls for a continuous adjustment of our skills. Any marketing strategy must take into account contemporary knowledge and the increasingly strict marketing activity requirements enhance our effectiveness in applying the knowledge. While all Member States can significantly increase their sales on accessing the EU market, they also face increased competition. Surviving in such a large market hinges on constantly following novelties and adapting to market conditions in the shortest time possible. A thorough understanding of the market we want to go in is therefore a prerequisite. Databases available online do not provide marketing managers with high-quality analysis of the market. It is, therefore, necessary to carry out a multitude of comparisons between individual EU countries. Only comparisons provide the neccessary focus as the outliers, maximums and minimums are deduced (Žugaj, Dumičić and Dušak, 2006) and cropped to detect a country's position within the EU market.

Similarly, as was the turning point of technological development of the industrial revolution at the beginning of the 2oth century, was a new turning point with the introduction of the wide use of information and communication technologies (ICT) at the end of the 2oth century. In agriculture the industrial revolution brought about the use of artificial fertilizers, at the end of the last century, but began production in agriculture of genetically modified crops for human or animal consumption. Such food has become an integral part of our daily diet. The effects of such diets require long-term studies and therefore, are still pretty unexplored area. Awareness of consumers of poultry meat, due to the use of ICT is very large and therefore, many consumers of all types of meat are already looking for someone who was reared by genetically modified feedingstuffs. Some producers of poultry meat in the markets already offer meat labeled GMO-free. However, the price received by producers for the production (the producer's price) is still one of the important factors that affect the competitive final price of meat on the market. In countries with higher standards is already possible to discern that they are knowledgeable buyers willing to pay a higher price for meat, which has been genetically modified food free reared.

This paper aims to determine the interrelations between production, import, export and producer prices of poultry meat in EU-28. The obtained results could be used by marketing managers to develop export strategies (Klemenčič, Devetak and Števančec, 2012). The most recent available data on the above variables are from 2011 (FAOstat, 2015). The data were collected from national annual reports on production and the Eurostat database (Eurostat, 2015). Furthermore, our objective is to identify country clusters based on population, imports, exports and poultry meat prices. The findings could inform marketing strategies and poultry sales in certain countries. 


\section{METHODOLOGY}

\subsection{Data sources}

From Faostat database are selected data of Production, Imports and Exports of all European Union state members (EU-28). Because the data are given in the 1.000 kilogram $(\mathrm{kg})$ what is equal to 1 ton $(\mathrm{t})$, we calculated by the unit before carrying out research in $\mathrm{kg}$ per capita, therefore, from the same base we select the data on the population of each country. Information on the producer's price are also picked from the same database Faostat, but in a survey in the base unit of US \$/t. FAOstat Division works directly with countries to develop their national statistical strategy, and advise on the improvement and development of their statistical programs. This information tells you that the data in the Member States of the UN are gathered from Faostat, so they use the same highly professional statistical methods. All Member States of the UNITED NATIONS in making the data must strictly respect the principles of the Paris Declaration on Aid Effectiveness, the Accra Agenda for Action, and the Dakar and Busan Declarations (2015).

It should be noted that data for Croatia, which joined the EU only in July 2013, are not published, so the data for Croatia were calculated by interpolation of the data published for Slovenia, because these two countries have very similar characteristics.

\subsection{Application of statistical cluster analysis}

Modern marketing research relies on the data collected by professional international agencies. In this research study, the data collected by FAOstat (2015), Eurostat (2015) and CIA World Factbook (2015) were analyzed using regression and cluster analysis. Wong (2009) used cluster analysis to study business opportunities and came to the conclusion that clustering could help in developing new marketing strategies. Simonič, Dumičić and Devetak (2012) used regression modelling to describe test for predicting poultry meat supply in European countries. They found a six-cluster solution when testing their research hypothesis that country clusters can be identified using four variables on poultry meat (production, exports, imports per capita, and producer price per quantity unit) provided that the variables are standardized and that Ward's linkage method and Euclidean distances are used.

\subsection{Food supply trends}

The global economic stagnation, including all EU member states (EU-28), led to a pronounced rise in unemployment. Providing food is becoming an increasingly important task for all EU member states. Although GMO-based feed has not as yet been well studied, producers are using genetically modified organisms (GMOs) in 
an attempt to increase grain yield per area unit (ha) and achieve long-term solutions (Hall, 2010). The Figure 1. reveals that 17 countries have increased the production of classic poultry in the period from 2009 to 2011 . In period from 2009 to 2011 the highest increase in production of poultry meat per capita achieved Lithuania $(+4.96$ $\mathrm{kg} /$ capita) whilst the highest decrease in poultry meat production had Bulgaria $(-3.09 \mathrm{~kg} /$ capita $)$ in the same period. Both, Croatia and Slovenia decreased their poultry meat production per capita in 2011 in compare to the production from 2009.

Figure 1.: Bar chart of differences in production of poultry meat in kg/capita in EU-28 countries between 2009 and 2011

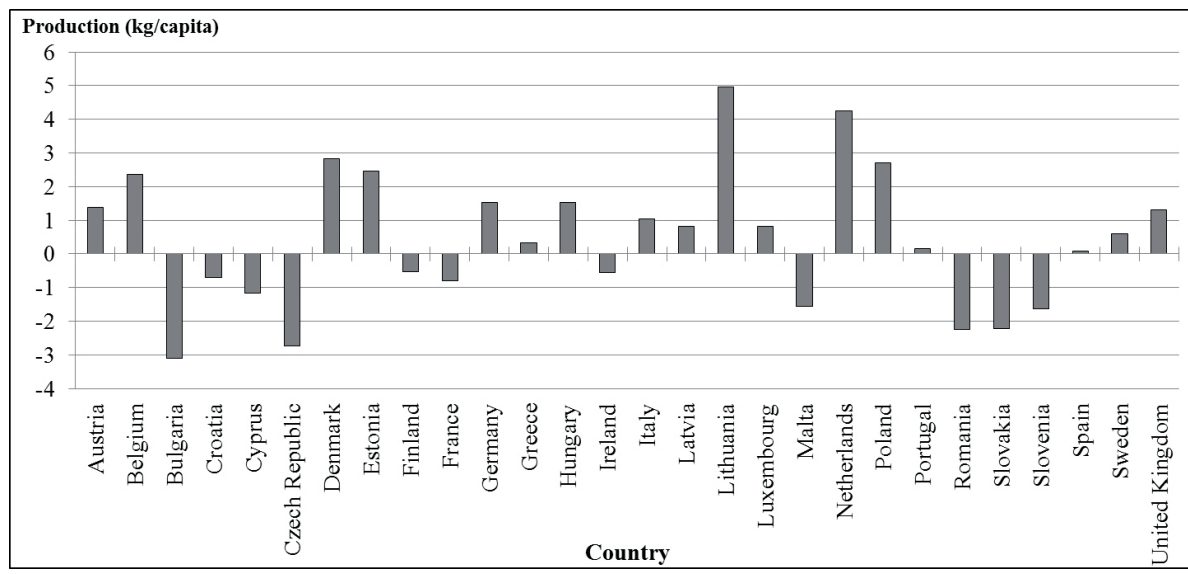

Source: Author's.

Table 1. presents the results of descriptive statistics for selected variables in 2009 and 2011. In 2011, it has been produced, on average, 22.14 $\mathrm{kg}$ per capita, which is $0.43 \mathrm{~kg}$ /capita more in compare to 2009 . Compared to 2009 , in 2011, the standard deviation increased $0.88 \mathrm{~kg} /$ capita, while the coefficient of variation increased from $5^{1 \%}$ to $54 \%$. Poultry meat production data distributions are positively skewed in both observed years.

On average, imports of poultry meat in the year 2011 amounted to $10.48 \mathrm{~kg} / \mathrm{cap}$ ita (in 2009 amounted to an average of $9.04 \mathrm{~kg} /$ capita) while the standard deviation was $7.82 \mathrm{~kg} /$ capita and $76 \%$ the coefficient of variation, which suggests that the variability was $2 \%$ lower than in 2009. Frequency distribution is a positive (skewness = 1.76) and peak is slightly sharper compared to normal distribution (kurtosis $=4.59$ ). The biggest importer among the researches countries is the Netherlands with $38.5^{8}$ $\mathrm{kg} /$ capita what is $3.10 \mathrm{~kg} /$ capita more in 2011 than in the 2009 . 
Table 1.: Results of descriptive statistics for variables: production, import, export \& producer price of poultry meat for EU-28 in 2009 and 2011

\begin{tabular}{|c|c|c|c|c|c|c|c|c|}
\hline \multirow[t]{2}{*}{ Statistics } & \multicolumn{2}{|c|}{$\begin{array}{l}\text { Production } \\
\text { (kg/capita) }\end{array}$} & \multicolumn{2}{|c|}{$\begin{array}{c}\text { Import Quantity } \\
\text { (kg/capita) }\end{array}$} & \multicolumn{2}{|c|}{$\begin{array}{l}\text { Export Quantity } \\
\text { (kg/capita) }\end{array}$} & \multicolumn{2}{|c|}{$\begin{array}{l}\text { Producer Price } \\
\text { (US } \$ / t)\end{array}$} \\
\hline & 2009 & 2011 & 2009 & 2011 & 2009 & 2011 & 2009 & 2011 \\
\hline $\begin{array}{l}\text { Number of } \\
\text { countries }\end{array}$ & 28 & 28 & 28 & 28 & 28 & 28 & 28 & 28 \\
\hline Mean & 21.72 & 22.14 & 9.04 & 10.4 .8 & 8.26 & 10.48 & $1,994.13$ & $2,131.81$ \\
\hline Minimum & 2.89 & 3.72 & 0.88 & 1.01 & 0.00 & 0.10 & $1,015.00$ & $1,008.28$ \\
\hline Maximum & $5^{0.72}$ & 54.96 & $35 \cdot 48$ & $38.5^{8}$ & $61.5^{2}$ & $7^{6} \cdot 7^{6}$ & $5,722.20$ & $6,337.10$ \\
\hline Range & 47.83 & $5^{1.24}$ & 34.60 & 37.57 & $61.5^{2}$ & $7^{6.66}$ & $4,707.20$ & $5,328.83$ \\
\hline $\begin{array}{l}\text { Population } \\
\text { standard } \\
\text { deviation }\end{array}$ & 10.84 & 11.72 & 6.89 & 7.82 & 12.85 & $15.5^{2}$ & 881.97 & $9^{3} 5.5^{\circ}$ \\
\hline Skewness & 0.81 & 0.99 & 2.12 & $1.7^{6}$ & 3.14 & 3.26 & 2.95 & 3.47 \\
\hline Kurtosis & 0.65 & 0.96 & 6.57 & 4.59 & 10.69 & 11.94 & 10.88 & 14.55 \\
\hline $\begin{array}{l}\text { Coefficient } \\
\text { of variation } \\
\text { (CV) }\end{array}$ & $0.5^{1}$ & 0.54 & $0.7^{8}$ & 0.76 & $1.5^{8}$ & $1.5^{1}$ & 0.45 & 0.45 \\
\hline ıst quartile & 13.35 & 13.21 & 5.07 & 5.07 & 1.83 & 2.32 & $1,543.33$ & $1,731.97$ \\
\hline Median & 19.33 & $19 \cdot 40$ & 7.69 & 9.22 & 3.54 & 5.06 & $1,685.60$ & 1,83०.04 \\
\hline 3rd quartile & 27.25 & 26.80 & 11.20 & 13.31 & 8.75 & 10.87 & $1,998.60$ & $2,182.97$ \\
\hline $\begin{array}{l}\text { Interquar- } \\
\text { tile range }\end{array}$ & 13.91 & 13.59 & 6.13 & 8.23 & $6.9^{3}$ & 8.55 & 455.28 & $45^{1.00}$ \\
\hline
\end{tabular}

Source: Author's.

In 2011 the average export volume was $10.48 \mathrm{~kg} /$ capita, which is for $2.22 \mathrm{~kg} /$ capita more than in 2009 and with an average deviation from the mean of $15.52 \mathrm{~kg} /$ capita, or relatively $20.8 \%$ in terms of relative standard deviation showing the decline of the variability in poultry meat export per capita for $4.5 \%$ relative to 2009 . The analyzed data of export are still quite far from a stable, normal distribution that is positively skewed (skewness=3.26). The Netherlands extremely increased its export at $76.76 \mathrm{~kg} /$ capita and still represents a serious outlier. Such a growth could be explained with the accession of new countries to the European Union, which do not have the borders, thus enabling the import of poultry meat under much lower prices.

The average poultry meat price in 2011 was $2,131.81 \mathrm{US} \$ / t$, which represents a $6.8 \%$ increase on the average price in 2009. The data for different countries varied considerably. Compared to 2009, the distribution of producer prices in 2011 was less skewed (skewness $=3.47$ ), but was still far from the normal distribution. The highest price of $6,33_{7} \mathrm{US} \$ / \mathrm{t}$ was recorded in Luxemburg. Producer prices in Italy decreased from 2,732 US $\$ / t$ in 2009 to $2,278 \mathrm{US} \$ / t$ in 2011. This drop in the price of poultry meat could be explained by the enlargement of the common market: the increased supply of poultry meat and the (lower) GDP of new member states. 


\section{Cluster analysis of all European Union member states (EU-28 regarding the poultry meat supply data in 2009 and in 2011}

The first research hypothesis $\left(\mathrm{H}_{1}\right)$ is EU-28 countries can be clustered into distinct groups on the basis of four variables related to poultry meat: production, exports and imports per capita, as well as producer price of poultry meat per quantity unit. Cluster analysis was therefore performed using standardised data, Ward's linkage method and Euclidean distances (Dumičić, Čeh Časni, Žmuk, 2015, Žmuk, 2015).

Figure 2.: Dendrogram of EU-28 countries based on four variables: production (kg/capita), export (kg/capita), import (kg/capita) and price (US \$/t) of poultry meat, 2009

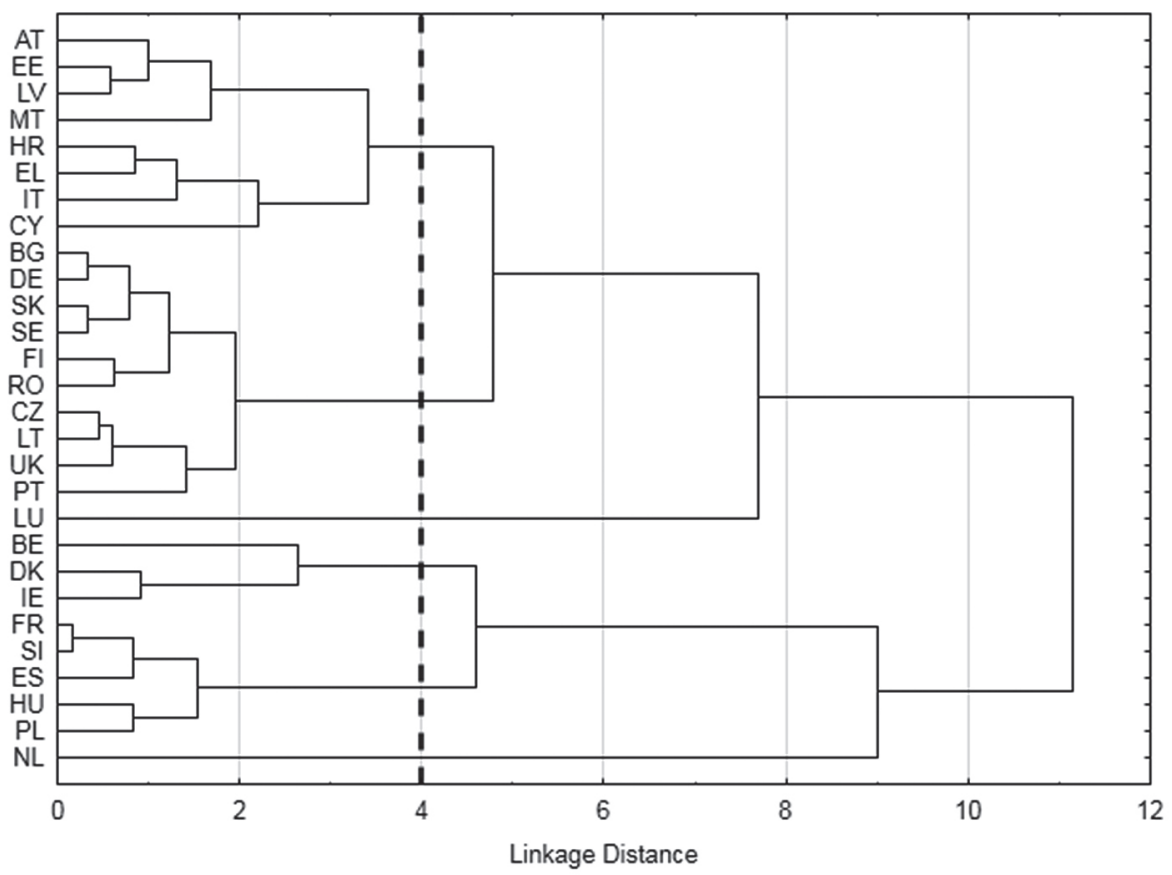

Source: Author's.

The Cluster 1 is comprised of 8 countries with exceptionally small amount of production, import and export, as well as with low producer prices of poultry meat. The exception in this cluster is Austria, where State with its agrarian policy pays farmers a subsidy and so keeps a low producer's price. These countries are: Austria, Croatia, Cyprus, Estonia, Greece, Italy, Latvia, and Malta.

The Cluster 2 consists of 10 countries: Bulgaria, Czech Republic, Finland, Germany, Lithuania, Portugal, Romania, Slovakia, Sweden, and United Kingdom. On 
average, these countries have similar values of production, import, export and prices- all variable are in mutual harmony. They have small standard deviations, which is also a one of the common factors that connect these countries.

The Cluster 3 is made of 1 country: Luxembourg is characterized as the low poultry meat producer, while producing only $229,000 \mathrm{t} / \mathrm{year}$ i.e. $2.89 \mathrm{~kg} / \mathrm{capita}$ of poultry meat, thus holding the last place in Europe. Luxembourg has a high population density $(185.6$ people per $\mathrm{km} 2$ ) but also does not have its own production, while export and import are far below the average in a relation to other European countries. However, this country has the highest producer prices of poultry meat in Europe of 5,722.2 US\$/t which is $4,00 \%$ above the European average. The reason for the highest price in Luxembourg can be explained by the types of meat that this country imports and exports. The import consists mainly of the most expensive parts, that is, from chicken fillets, which have up to 3 times higher price than other parts of the chicken.

In Cluster 4 there are Belgium, Denmark and Ireland. These countries have connections between two pairs of economic features and dependent variables. The first pair is presented by the production and producer prices. The countries in this Cluster are diametrical opposites. They have relatively high poultry meat production, while on the other hand the producer prices are low. The second feature of these countries is a positive difference of lower import and higher export (export surplus). This diametrical opposite provides them a competitive advantage and the possibility for higher GDP as well as the background for new investments and the industrial development.

Cluster 5 includes France, Hungary, Poland, Slovenia and Spain. The interaction within the cluster reveals that Slovenia and France coincide in all four variables. Hungary and Poland deviate from the cluster average with a lower producer price and higher production per capita. Spain differs from the average in terms of lower import and lower export quantities. Countries in this cluster have similar average values, but their marketing strategies should be designed taking into consideration the underclusters, as shown in Figure 2.

Finally, Cluster 6 consists of only one country, the Netherlands. It is on the first place per production quantities with $50.72 \mathrm{~kg} /$ capita, but noted that EU legislation allows specifying each country as the producer of the poultry meat production, which implements the final packaging of the products. That leaves the possibility that the Netherlands is listed as the producer, even though he only pre-package the imported goods. It is also a logical explanation for the high import and export of these relatively small European countries with 16.6 million inhabitants. Compared to other European countries, the exports of poultry meat from the Netherlands were $7_{1} 3.7 \%$ above the average of EU $(8.62 \mathrm{~kg} /$ capita). The export quantities from Netherland is equal to export of Belgium and Denmark which are placed second and third, respectively, in terms of the quantity of poultry meat exported.

Further, clustering is made for the same variables and the same countries for 2011. In Figure 3. the clusters of EU-28 countries according to conducted cluster 
analysis results based on standardized variable values, Ward's method and Euclidean distances the are given.

In 2011 Cluster 1 was comprised of 3 countries only: Austria, Cyprus and Greece. Croatia, Estonia, Latvia and Malta moved to cluster 2, while Italy moved to cluster 3 due to a pronounced fall in producer prices. Countries in cluster 1 were characterized by a relatively low domestic production of poultry meat. Consequently, with imports significantly higher than exports of poultry meat, they were import-oriented. The trade deficit (export - import = deficit) in poultry meat was negative and amounted for Austria -3.94 kg/capita, for Cyprus - $4.02 \mathrm{~kg} /$ capita and for Greece $-8.18 \mathrm{~kg} /$ capita, respectively.

Figure 3.: Dendrogram of EU-28 countries based on four variables: production (kg/capita), export ( $\mathrm{kg} /$ capita), import (kg/capita) and price (US \$/t) of poultry meat, 2011

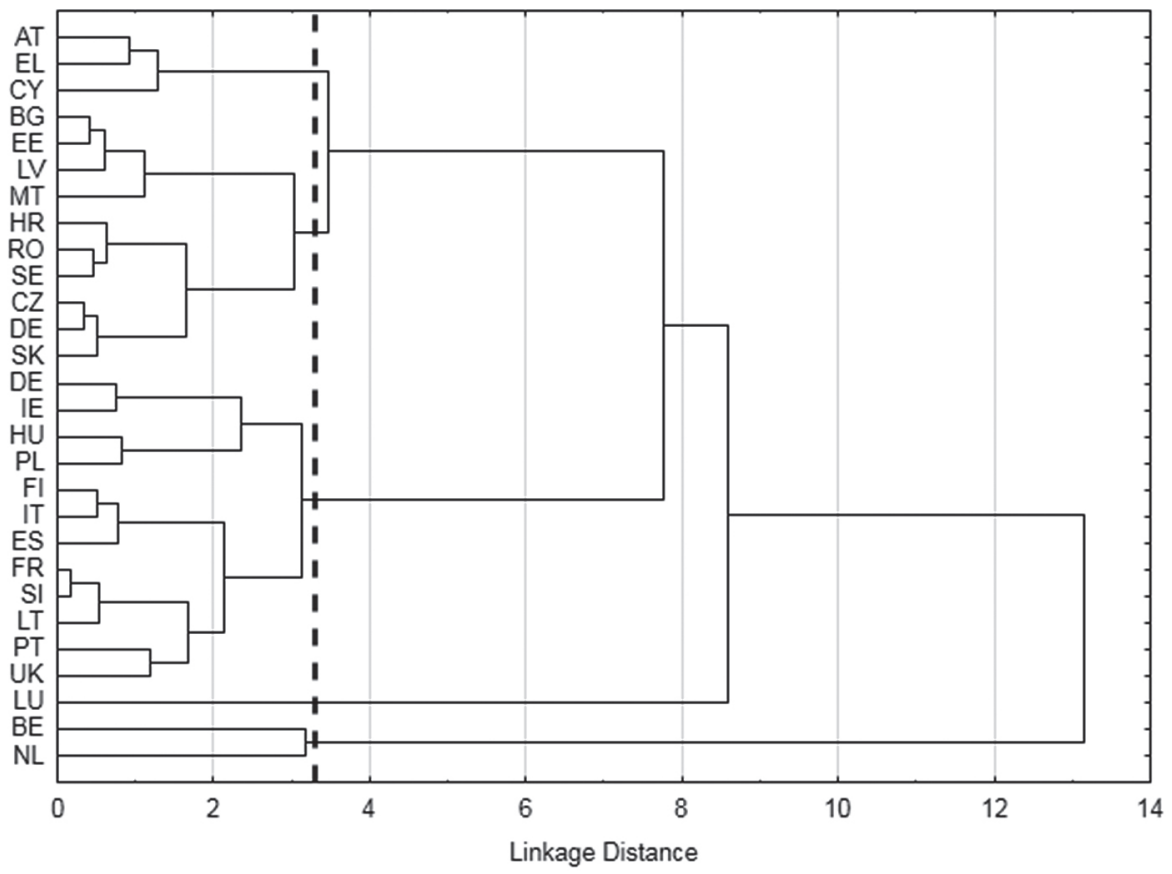

Source: Author's.

Cluster 2 was made of 10 countries in 2009. Bulgaria, the Czech Republic, Germany, Romania, Slovakia and Sweden maintained their place in cluster 2 and were joined by Croatia, Estonia, Latvia and Malta from cluster 1 in 2011. Simultaneously, Finland, Lithuania, Portugal and the United Kingdom moved to cluster 3 in 2011. Cluster 2 countries were jointly characterized by a low production of poultry meat per capita, which was below under average of the annual EU-28 production quantities of $22.14 \mathrm{~kg} /$ capita in 2011 . Even though these countries export poultry meat, they are 
mostly import-oriented and have a huge export deficit in products obtained from poultry meat.

Cluster 3 included 12 countries: Denmark, Finland, France, Hungary, Ireland, Italy, Poland, Portugal, Lithuania, Slovenia, Spain and the United Kingdom. These countries are characterized by a high production of poultry meat per capita, i.e. their production was above average of the annual EU-28 production quantities of $22.14 \mathrm{~kg} /$ capita in the year 2011. These countries also export more than they import and consequently have a big export surplus in products obtained from poultry meat. These countries are export-oriented.

There was only one country in cluster 4: Luxembourg, which was one of the three outliers. In 2011 this cluster was characterized by the lowest domestic production, amounting to barely $3.72 \mathrm{~kg} /$ capita, the third-largest volume of imports $\left(22.7^{1} \mathrm{~kg} /\right.$ capita) and the highest producer price of poultry meat $(6,337 \mathrm{US} \$ / \mathrm{t})$. Poultry meat exports of Luxembourg were very small, amounting to only $2.27 \mathrm{~kg} / \mathrm{capita}$, which was far from the average of the EU-28 of $10.48 \mathrm{~kg} /$ capita. In 2011, Luxembourg had the largest export deficit in EU-28 of $-20.44 \mathrm{~kg} /$ capita. This country is import-oriented.

Cluster 5 included Belgium and the Netherlands. In comparison with other EU-28 states, Belgium had the second highest production volume (46.36 kg/capita), the third highest import volume $(20.44 \mathrm{~kg} /$ capita $)$ and the second highest export volume (43.80 kg/capita). The Belgian production was higher for $24.22 \mathrm{~kg} /$ capita than the average production in EU Member States-28 (22.14 kg/capita). Export was greater for $33.32 \mathrm{~kg} /$ capita than the value of the exports average of the EU-28 (10.4.8 $\mathrm{kg} /$ capita). The average producer price of poultry meat of countries in the cluster is $1,786 \mathrm{US} \$ / \mathrm{t}$ which is for $345 \mathrm{US} \$ / \mathrm{t}$ lower than the average producer price in all $28 \mathrm{EU}$ member states $(2,131$ US $\$ / t)$. The Netherlands had the largest production of poultry meat in the EU-28 (54.96 kg/capita), the highest import volume $\left(38.5^{8} \mathrm{~kg} /\right.$ capita), the highest export volume $(76.76 \mathrm{~kg} /$ capita) and production price among the lowest in the EU $(1,684, \mathrm{US} \$ / \mathrm{t})$ : as much as $447 \mathrm{US} \$ / \mathrm{t}$ lower than the average of the EU-28. Compared to the rest of the EU-28, the Netherlands recorded the largest difference between imports and exports of products obtained from poultry meat. Its trade surplus in poultry meat was $38.19 \mathrm{~kg} /$ capita. High export volumes can be attributed to the relatively low price. That is to say, the most upmarket of the imported goods (mainly chicken fillet) reaches the EU market at the lowest prices through the Netherlands' biggest shipping ports (Rotterdam and Amsterdam). These two countries are both export-oriented.

From 2009 to 2011, 22 countries were within Clusters 2 and 3, which represented $78.5 \%$ of the all European Union state members (EU-28). It seems highly probable that a single variable affected the results for the majority of EU-28 as in 2011 the countries were most evenly spread than in 2009. This unification may logically be explained by the openness of the EU market. 


\section{CORRELATION AND MULTIPLE REGRESSION ANALYSIS OF ALL EUROPEAN UNION MEMBER STATES (EU-28) REGARDING THE POULTRY MEAT SUPPLY DATA IN 2009 AND IN 2011}

Correlation matrix consists of the coefficients of linear correlation between variables of production, import, export and producer price of poultry meat. The correlation matrix based on data from 2009 is given in Table 2. whereas the correlation matrix based on data from 2011 is presented in Table 3.

Table 2.: Correlation matrix of variables production, import, export and producer price of poultry meat, EU-28 countries, 2009

\begin{tabular}{|l|r|r|r|r|}
\hline & $\begin{array}{c}\text { Production } \\
\text { (kg/capita) }\end{array}$ & $\begin{array}{c}\text { Import } \\
\text { (kg/capita) }\end{array}$ & \multicolumn{1}{|c|}{$\begin{array}{c}\text { Export (kg/ } \\
\text { capita) }\end{array}$} & $\begin{array}{c}\text { Producer price } \\
\text { (US\$ } \mathbf{t} \text { ) }\end{array}$ \\
\hline $\begin{array}{l}\text { Production } \\
\text { (kg/capita) }\end{array}$ & 1.0000 & & & \\
Import (kg/capita) & 0.2724 & 1.0000 & & \\
Export (kg/capita) & $0.7831^{* *}$ & $0.7072^{* *}$ & 1.0000 & \\
$\begin{array}{l}\text { Producer price } \\
\text { (US\$/t) }\end{array}$ & $-0.4480^{*}$ & 0.0868 & -0.2584 & 1.0000 \\
\hline
\end{tabular}

* - correlation is significant at the 0.05 level (2-tailed)

** - correlation is significant at the 0.01 level (2-tailed)

Source: Author's.

Table 3.: Correlation matrix of variables production, import, export and producer price of poultry meat, EU-28 countries, 2011

\begin{tabular}{|l|r|r|r|r|}
\hline & $\begin{array}{c}\text { Production } \\
\text { (kg/capita) }\end{array}$ & $\begin{array}{c}\text { Import } \\
\text { (kg/capita) }\end{array}$ & $\begin{array}{c}\text { Export (kg/ } \\
\text { capita) }\end{array}$ & $\begin{array}{c}\text { Producer price } \\
\text { (US\$/t) }\end{array}$ \\
\hline $\begin{array}{l}\text { Production } \\
\text { (kg/capita) }\end{array}$ & 1.0000 & & & \\
Import (kg/capita) & 0.2957 & 1.0000 & & \\
$\begin{array}{l}\text { Export (kg/capita) } \\
\begin{array}{l}\text { Producer price } \\
\text { (US\$/t) }\end{array}\end{array}$ & $0.8061^{* *}$ & $0.7055^{* *}$ & 1.0000 & \\
\hline
\end{tabular}

* - correlation is significant at the 0.05 level (2-tailed)

** - correlation is significant at the 0.01 level (2-tailed)

Source: Author's.

Correlation coefficients show that positive linear correlation exists between variables Production, Import and Export considered for 2009 and 2011. Variables Production and Export are highly positively correlated with correlation of $r=0.7831$ in 2009 and $r=0.8061$ in 2011. Variables Import and Export are moderately positively correlated in 2009 and in 2011 (r2009=0.7072, r2011=0.7055). On the other side, variable Producer price is negatively correlated with variable Production in both 
observed years. So, variable Producer price is moderately negatively correlated with variable Production $\left(\mathrm{r}_{2} \mathrm{O} 0 \mathrm{O}=-0.44,8 \mathrm{O}, \mathrm{r} 2 \mathrm{O} 11=-0.3833\right)$. All mentioned correlations seem to be statistically significant at significance level $5 \%$.

With a purpose to test the second research hypotheses $\mathrm{H}_{2}$, that there is at least one variable that is statistically significant for an explanation of poultry meat production in $\mathrm{kg} / \mathrm{capita}$, the multiple linear regression analysis was conducted (Dumičić, Žmuk and Palić, 2014). In the model variable Production of poultry meat in kg/capita is a dependent variable whereas the other variables are considered as independent (Import of poultry meat in kg/capita, Export of poultry meat in kg/capita, Producer price in US $\$ / t$ ). The best statistical properties and results were shown when variables Import and Export were included in the regression model as independent variables. It has to be emphasized that variable Producer price in US $\$ / t$ has statistically significant correlation with variable Production of poultry meat in $\mathrm{kg} /$ capita but that independent variable come is not statistically significant in the multiple regression models. Consequently, following multiple linear regression model for the population is analyzed in detail:

$$
\text { Production }_{i}=\beta_{0}+\beta_{1} \cdot \text { Import }_{i}+\beta_{2} \cdot \text { Export }_{i}+e_{i}, \quad i=1,2, \ldots, n
$$

Furthermore, appropriate model for the sample in this case is:

$$
\text { Production }_{i}=\hat{\beta}_{0}+\hat{\beta}_{1} \cdot \text { Import }_{i}+\hat{\beta}_{2} \cdot \text { Export }_{i}, \quad i=1,2, \ldots, 28
$$

Estimates are calculated using an ordinary least squares method (OLS) for 2009 and 2011. In order to estimate multiple regression models data for all European Union state members (EU-28) were used.

$$
\begin{aligned}
& \text { Production }_{i}=21.4967-0.8855 \cdot \text { Import }_{\mathrm{i}}+0.9964 \cdot \text { Export }_{\mathrm{i}} \\
& \begin{array}{lll}
(1.7600) & (0.2127) \quad(0.1140)
\end{array} \\
& R^{2}=0.7716 \quad \bar{R}^{2}=0.7534 \quad R=0.8784 \\
& \hat{\sigma}=5.48 \quad \hat{V}=25.25 \% \quad D W=2.397 \quad n=28
\end{aligned}
$$

Appropriate regression diagnostic was conducted and it was concluded that all multiple regression model assumptions are fulfilled. So, the multicollinearity test using Variance Inflation Factor (VIF) criteria showed that VIF statistic is 2.000 what is considerably lower than 5 . Consequently, it has been concluded that there is no multicollinearity problem in the model. Next it was tested if the residual variance in a regression model is constant or not. Both conducted tests, Breusch-Pagan-Godfrey (test statistic $=2.5^{84}, \mathrm{p}$-value $\left.=0.2747\right)$ and White $($ test statistic $=4.414, \mathrm{p}$-value $=$ $0.4915)$ tests, have shown than it can be concluded that, at significance level $5 \%$, the residual variance in a regression model is constant. The existence of significant 
correlation between error terms ordered in time was inspected using DurbinWatson and Ljung-Box test. Since the test value for Durbin Watson test is DW = 2.397, so that $2<\mathrm{DW}<4$, the test for negative autocorrelation of residuals was conducted. The computed DW is smaller than the table value $4-\mathrm{d}_{\mathrm{U}}=2.441$ at significance level $5 \%$, so the test indicates that there is no negative autocorrelation of the first order. In addition, Ljung-Box test showed that there is no autocorrelation of residuals up to the 12th order at significance level $5 \%$. The Jarque-Bera test of normality (test statistic $=0.5^{80}, \mathrm{p}$-value $\left.=0.7483\right)$ for residuals was applied. The test has shown that the null-hypotheses that the residuals are normally distributed may not be rejected at significance level of $5 \%$.

The coefficient of determination, $\mathrm{R}^{2}=0.77^{16}$, means that $77.16 \%$ of the variation in Production of poultry meat is explained by both Import and Export of the same kind of meat. Consequently, the coefficient of correlation, $\mathrm{R}=0.8784$, is considerably high what goes in favour of conclusion that there is a strong relation between Production of poultry meat on the one side and Import and Export of poultry meat on the other side. The conducted F-test (test statistic $=42.233, \mathrm{p}$-value $<0.0001$ ) showed that the model in general is statistically significant at significance level of $1 \%$. The regression standard error is $5.4 .8 \mathrm{~kg} /$ capita and regression coefficient of variation is $25.25 \%$, meaning the model is representative.

The regression coefficient of the regressor variable Import is negative but statistically significant at significance level of $1 \%(\mathrm{t}$-statistic $=-4.164, \mathrm{p}$-value $=$ ○.0003). So, based on the estimated equation, remaining Export unchanged, a one unit increase in Import (kg/capita) decreases Production of poultry meat on average by $0.8855 \mathrm{~kg} /$ capita. The regression coefficient of the regressor variable Export is positive and statistically significant at significance level of $1 \%(\mathrm{t}$-statistic $=8.737, \mathrm{p}-$ value $<0.0001)$. So, based on the estimated equation, remaining Import unchanged, a one unit increase in Export (kg/capita) increases Production of poultry meat on average by $0.9964 \mathrm{~kg} /$ capita. The standardized parameters of variables Import ( $\beta$-hat ${ }_{1}$ $=-0.5629)$ and Export $\left(\beta-\right.$ hat $\left._{2}{ }^{*}=1.1812\right)$ show that variable Import has lower relative impact on variable Production of poultry meat than variable Export.

Multiple regression model with estimated parameters for the year 2011 is following:

$$
\begin{gathered}
\text { Production }_{i}=21.2531-0.8140 \cdot \text { Import }_{\mathrm{i}}+0.8984 \cdot \text { Export }_{\mathrm{i}} \\
(1.8055) \quad(0.1899) \quad(0.0958) \\
R^{2}=0.7981 \quad \bar{R}^{2}=0.7819 \quad R=0.8934 \\
\hat{\sigma}=5.57 \quad \hat{V}=25.17 \% \quad D W=2.544 \quad n=28
\end{gathered}
$$

The conducted detailed regression diagnostic showed that the regression model met all requirements. The multicollinearity test using Variance Inflation Factor (VIF statistic $=1.991)$ showed that independent variables are not highly correlated and so their separate influence on the dependent variable can be easily distinguished. The 
conducted heteroskedasticity test, Breusch-Pagan-Godfrey (test statistic $=1.774$, $\mathrm{p}$-value $=0.4118)$ and White (test statistic $=5.955, \mathrm{p}$-value $=0.3106)$ tests, have shown than it can be concluded that, at significance level $5 \%$, the residual variance in a regression model is constant and that the heteroskedasticity problem is not present in the model. The Durbin-Watson test was used to inspect the existence of significant correlation between error terms ordered in time. Since the test value for Durbin Watson test is DW $=2.544$, so that $2<\mathrm{DW}<4$, the test for negative autocorrelation of residuals was conducted. The Durbin-Watson test statistic is smaller than the table value $4-\mathrm{d}_{\mathrm{U}}=2.675$ at significance level $1 \%$, so the test indicates that there is no negative autocorrelation of the first order. The Ljung-Box test results have also pointed out that there is no autocorrelation problem in the model at significance level $5 \%$. According to the Jarque-Bera test of normality results (test statistic $=0.15^{3}$, $\mathrm{p}$-value $=0.9266$ ) it can be concluded that the residuals are normally distributed at significance level of $5 \%$.

The regression model successfully explained $79.81 \%\left(\mathrm{R}^{2}=0.7981\right)$ of the variation in Production of poultry meat by variables Import and Export of the same kind of meat. The coefficient of correlation $(R=0.8934)$ reveals strong correlation between Production of poultry meat on the one side and Import and Export of poultry meat on the other side. The overall F-test of significance of the multiple regression (test statistic $=49 \cdot 4.06, \mathrm{p}$-value $<0.0001)$ indicates that two independent variables Import and Export together are statistically significant for explanation of Production of poultry meat per capita in EU-28 countries. The regression standard error is $5.4 .8 \mathrm{~kg} /$ capita and regression coefficient of variation is $25.25 \%$, meaning the model is representative.

The regression coefficient of the regressor variable Import is negative but statistically significant at significance level of $1 \%(\mathrm{t}$-statistic $=-4.286, \mathrm{p}$-value $=$ 0.0002). So, based on the estimated equation, remaining Export unchanged, a one unit increase in Import (kg/capita) decreases Production of poultry meat on average by $0.8140 \mathrm{~kg} /$ capita. The regression coefficient of the regressor variable Export is positive and statistically significant at significance level of $1 \%\left(\mathrm{t}\right.$-statistic $=9.380, \mathrm{p}^{-}$ value $<0.0001$ ). So, based on the estimated equation, remaining Import unchanged, a one unit increase in Export (kg/capita) increases Production of poultry meat on average by $0.8984, \mathrm{~kg} /$ capita. The standardized parameters of variables Import ( $\beta$-hat ${ }_{1}{ }^{*}$ $=-0.5434)$ and Export $\left(\beta\right.$-hat $\left.{ }_{2}{ }^{*}=1.1894\right)$ show that variable Import has lower relative impact on variable Production of poultry meat than variable Export. 


\section{CONCLUSION}

In this study selected multivariate analysis methods were used to explore developing marketing strategy of poultry meat supply in the EU state members (EU28). In the analysis following variables were used: production, import and export, expressed in units of $\mathrm{kg} / \mathrm{capita}$ and the producer's price expressed in the unit of US $\$ / t$. For an overview of market potentials we studied the relationships between these variables of selected countries.

In the first part of the research EU-28 countries are clustered into distinct groups on the basis of four variables related to poultry meat: production, exports and imports per capita, as well as producer price of poultry meat per quantity unit in 2009 and 2011. In the hierarchical cluster analysis approach Ward linkage method and the Euclidean distance were used.

In 2011 the Cluster 1 is comprised of 3 countries, as follows: Austria, Cyprus and Greece. Cluster 2 is consisted of 10 countries, which are similar considering clustering variable, and these are: Bulgaria, Croatia, Czech Republic, Estonia, Germany, Latvia, Malta, Romania, Slovakia und Sweden. Cluster 3 is made by 12 countries: Denmark, Finland, France, Hungary, Ireland, Italy, Lithuania, Poland, Portugal, Slovenia, Spain, the United Kingdom. Cluster 4 is consisted of 1 country: Luxemburg. A Cluster 5 covers 1 country: Belgium. And, finally, there is Cluster 6, which includes 1 country and that one is The Netherlands. Countries comprising one cluster have similar characteristics considering all four variables on poultry meat, so, the research hypothesis $\mathrm{H}$ c can be accepted.

In the year 2011, it was half of the European Union state members (EU-28) export-oriented. These have been members of the clusters three, five and six. Because of awareness of the growing demand for poultry meat these countries have large investments to expanse theirs production of meat. As indicated by Eurostat (Eurostat, 2014) the price of agricultural industrial crops for the period 2010 to 2014 increased by $6 \%$, while the price of the crops increased by only $4.3 \%$ (the same period). The logical explanation is the increased supply of quality meat reared to higher standards (IFS, BRC, STS, BTS), which achieved a higher price in the market, so it is realistic to expect in the future to growth of prices of poultry meat. However, the EU market is becoming increasingly difficult because customers are ever more informed and buy only products that are safe and provide adequate quality.

Analysis of the data showed that the Member States are referred to cluster 2 as an import oriented countries with high export deficit the most important potential customers for the producer's of cluster 3 , which are export-oriented and have a large export surplus. With a good marketing strategy for the country from a cluster of 3 as possible buyers of the interesting countries are from cluster 1, which primarily are attractive due to its country size and high producer prices and, consequently, as well as the market price. The Member States referred to in clusters 4, 5 and 6 (Luxem- 
burg, Belgium and the Netherlands) are atypical. Doing business with them is harder, because the same operating outside EU borders in poultry meat. In particular, they focused on imports large quantities from South America and recently in China, where imported products with lower price and quality of the goods.

In order to inspect the second research hypothesis $\left(\mathrm{H}_{2}\right)$, which states that at least one variable is statistically significant for explaining poultry meat production per capita, a multiple regression model was created for each of the two years considered, 2009 and 2011. A comparison of the two multiple regression models based on two regressors, Exports and Imports in EU-28 countries, revealed that both models are of satisfactory quality. In both multiple regression models the variable Imports has a negative individual impact on Production of poultry meat whereas the variable Exports has a positive impact. Considering the differences in the impact of variables Imports and Exports in 2009 and 2011, it can be concluded that was no significant change occurred. It has, however, been shown that the variable Imports had a lower relative impact on the variable Production of poultry meat than the variable Exports in both years.

Both regression models confirmed the second research hypothesis $\left(\mathrm{H}_{2}\right)$ which leads to the conclusion that the production of poultry meat depends on the agricultural policy of individual countries and their investment in agriculture development. Due to the high transport costs of animal feed are also very important location of countries (ports, large agricultural areas for the production of their own feed, low price of labor). Both regression models have got all model assumptions fulfilled, so, they may be used for predictions.

As the main limitation of the research the used old data can be considered. Unfortunately, this was unavoidable because the Faostat database is not regularly updated and there is huge lag between present year and the last year for which data are available. 


\section{REFERENCES:}

Bamiro, O.M., Momoh, S. and Phillip D.O.A., "Vertical integration and Profitability in Poultry Industry", available at: http://www.krepublishers.com/o2-Journals/JHE/JHE-27-0-০o०-o9-Web/JHE-27-2-০o०09-Abst-PDF/JHE-27-02-149-09-1834-Bamiro-O-M/JHE-27-02-149-09-1834-Bamiro-O-M-Tt. pdf, (2009)

CIA, "World Factbook", available at: https://www.cia.gov/library/publications/the-world-factbook/geos/ gm.html, (2015)

Dumičić, K., Čeh Časni, A. and Žmuk, B., "Internet Purchases by Individuals: Clusters of the Most vs the Least Developed European Countries", International Journal of Information Technology \& Computer Science, Vol. (18), (2015): 1-9

Dumičić, K., Žmuk, B. and Palić, I., "Web Page Use by Enterprises in European Union: Multiple Regression Analysis Approach", Journal of American Business Review, Vol. (2), (2014): 180-186

Eurostat, "Projected old-age dependency ratio", available at: http://epp.eurostat.ec.europa.eu/tgm/graph. do?tab=graph\&plugin= $1 \&$ language $=$ en\&pcode=tsdde $511 \&$ toolbox=type,$(2015)$

Eurostat, "Agricultural accounts and prices", available at: http://ec.europa.eu/eurostat/statisticsexplained/index.php/Agricultural_accounts_and_prices\#Price_indices, (2015)

FAOstat. „Guiding Principles of the FAO Statistics Division“, available at: http://www.fao.org/fileadmin/ templates/ess/documents/Media_and_Communication/Brochures/ESS_vision.pdf, (2015)

Hall, C.R., "Genetically modified food and crops: perception of risk". available at: http://hdl.handle. net/1842/4719, (2010)

Klemenčič, B., Devetak, G. and Števančec, D., "Intercultural differences in the purchase and information behavior of young consumers", Organizacija, Vol. (45), No. (1), (2012): 14,-23

Simonič, M., Dumičić, K., Devetak, G., "Regression Analysis of Variables Describing Poultry Meat Supply in European Countries", Organizacija, Vol. (45), No. 6, (2012): 289-299

Vida, I., Kos Koklič, M. and Kunz, M. B., "A study of counterfeiting purchase behavior: the role of percieved consequences and neutralization", (Chicago, Marketing Management Association, 2012)

Vukasović, T., "Consumer perception of poultry meat and the importance of country of origin in a purchase making process", World's Poultry Science Journal, Vol. (65), (2009): 65-74

Wong, A. W., "Cluster building by policy design: a sociotechnical constituency study of information communication technology (ICT) industries in Scotland and Hong Kong", available at: http://hdl.handle.net/1842/4091, (2009)

Žmuk, B., "Selling Online by European Enterprises - Multivariate Analysis Approach", International Journal of Engineering Business Management, Vol. (7), (2015): 1-8

Žugaj, M., Dumičić, K. and Dušak, V., "Temelji znanstvenoistraživačkog rada: Metodologija i metodika", (Varaždin, Sveučilište u Zagrebu, Fakultet organizacije i informatike, 2006) 
